\title{
P. Théad. 48 and the epikephalaion*
}

$W^{n}$

HEN studying $P$. Théad. No. 48, one is immediately struck by two anomalies : 1) the reading of the last (13th) line of the first

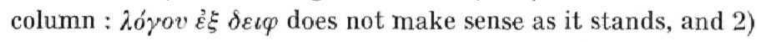
the two lines of column II are - to say the least - not very clear.

In the first column of the papyrus under review twelve moneypayments are listed. At the end of an enumeration of payments one expects to find the sum total. A glance at the photograph would convince everybody that line 13 of column I reads : ( $\left.\gamma^{i} v \varepsilon \tau \alpha \iota\right)$ ó $\mu \sigma \tilde{v}\left(\tau \alpha^{\prime} \lambda a v \tau \alpha\right)$ $\xi \delta(\delta \varrho \alpha \chi \mu \alpha i) \varphi$.

Adding up the amounts mentioned in lines 1-12 (1), one arrives, however, at a total of 66 talents and 500 drachms, i.e. 2 talents more than the sum total given in line 13 of the first column of the papyrus. In the second column, however, two amounts are subtracted from the sum total. Before writing down the sum total in line 13 of the first column, the scribe made a separate addition, deducted the two amounts mentioned in the two lines of the second column, and only then noted down the ultimate sum total. Added up, the amounts given in the two lines of the second column should amount to 2 talents to arrive at the sum total of 64 talents 500 drachms, unless the scribe made a mistake. In our opinion the amounts mentioned in the two lines of the second

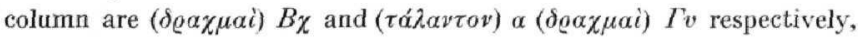
i.e. 2 talents together. So the ultimate sum total given in line 13 of column I tallies.

When in the two lines of column II one observes twice $\pi \tau$ with an oblique drawn through both letters, one is at once reminded of $\pi(\varrho \iota \mu \iota)$ -

* Prcf. Jean Bingen kindly sent us a photograph of the papyrus under review (cf. L. Koenen-H. Riad, Das photographische Archiv griechischer Papyri, ZPE.11,

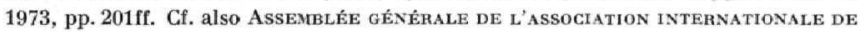
Papyrologues, Oxford, 31.7. 1974. Projet de Procès Verbal; L. Koenex, Fieldwork of the International Photographic Archive in Cairo. Studia Papyrologica 15 (1976), pp. 50 sqq.). It appears that at the left-hand side of the papyrus a part has been lost in the time between the date of the original publication by $P$. Jouguet and the taking of the photograph.

(1) Scme of the amounts were wrongly transcribed by Jougust. In lines 3 and 6

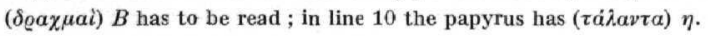


$\pi(i \lambda$ ov) (1). We know from $P$. Oxy. XVI 1905, 10 that in the late ivth (or early vth) century A.D. $\left({ }^{2}\right)$ the assessment of this tax was based on land. In the second line of column II we read $\gamma \tilde{\eta} \varsigma$ instead of $\tau \tilde{\eta} s$, and transcribe this whole line as follows: $x \alpha i$ vi $\pi(\dot{\varepsilon} \varrho) \pi(\varrho \iota \mu) \pi(i \lambda \omega v) \gamma \tilde{\eta} \varsigma \quad \dot{v} \pi(\dot{\varepsilon} \varrho) x \gamma$

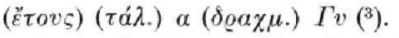

In the first line of this column, however, another payment for $\pi(\varrho \iota \mu t)$ $\pi(i \lambda \Delta v)$ for the same 23rd year is made, but in this case the word follow-

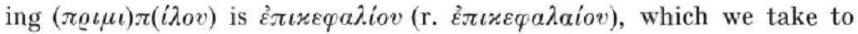
be an adjective $\left.{ }^{4}\right): \dot{\varepsilon} \xi \tilde{\omega} v \pi(\varrho \iota \mu \iota) \pi\left(i \lambda_{0 v}\right) \dot{\varepsilon} \pi \iota x \varepsilon q \alpha \lambda i o v \varkappa \gamma(\tilde{\varepsilon} \tau \sigma v \varsigma)(\delta \varrho \alpha \chi-$ uai) $B \chi$

We deduce from these two payments that the tax called $\pi(\varrho \iota \mu \iota) \pi(i \lambda o v)$ was not only based on land, but also on persons.
University of Amsterdam
P. J. SiJPESTEIJN - K. A. WorP

(1) Cf. P. Cairo Isid. 61,9 note ad loc.; J. LALLEMAND, L'administration civile de l'Égypte de l'avènement de Dioclétien à la création du diocèse (284-382), Bruxelles, 1964 , p. 205, which does not mention P. Cairo Isid. 61, though.

(2) Cf., however, Lallemand, op, cit., p. 184, note 5.

(3) The 23rd year is in all probability the 23rd year of Galerius (cf. P. Cairo Isid. 122,5 note). This would imply that $P$. Théad. No. 48 has to be dated to $314 / 315$ A.D. Cf. A. Chastagnol, La datation par années régnaies égyptiennes à l'époque constanlinienne, dans Aiôn, le temps chez les Romains (Paris 1976), pp. 221-238.

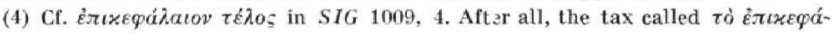
$\lambda \alpha \iota v$ is nothing but $\tau \dot{o} \dot{\varepsilon} \pi \iota x \varepsilon \varphi a \dot{\lambda} \alpha \iota v$ (sc. $\left.\tau \dot{\lambda} \lambda o_{\varsigma}\right)$. 